\title{
Brand Awareness, Brand Image Dan Brand Loyalty Sebagai Prediktor Brand Equity Adidas
}

\author{
Novia Agnes dan Happy Darmawan \\ Program Studi SI Manajemen Fakultas Ekonomi Universitas Tarumanagara, Jakarta \\ Email :noviiagnes@gmail.com
}

\begin{abstract}
The purpose of this study to examine whether brand awareness, brand image and brand loyalty can predict brand equity Adidas in Jakarta. The population in this study were Adidas consumers in Jakrata. The sample was 100 respondents with a convenience sampling technique questionnarise ans using SmartPLS 3 software. Overall, the result of this research were brand awareness positive and significant as a predictor of brand equity, brand image positive and significant as a predictor of brand equity, and brand loyalty positive and significant as a predictor of brand equity.
\end{abstract}

Keywords: brand awareness, brand image, brand loyalty, brand equity

\begin{abstract}
Abstrak: Tujuan dari penelitian ini adalah untuk menguji apakah brand awareness, brand image dan brand loyalty dapat memprediksi brand equity Adidas di Jakarta. Populasi dalam penelitian ini adalah konsumen Adidas di Jakarta. Sampel adalah 100 responden dengan kuesioner teknik convenience sampling dan menggunakan perangkat lunak SmartPLS 3. Secara keseluruhan, hasil dari penelitian ini brand awareness secara positif dan signifikan menjadi prediktor brand equity, brand image secara positif dan signifikan menjadi prediktor brand equity, brand loyalty secara positif dan signifikan menjadi prediktor brand equity Adidas.
\end{abstract}

Kata Kunci: kesadaran merek, citra merek, loyalitas merek, ekuitas merek

\section{LATAR BELAKANG}

Pada era globalisasi jaman sekarang yang terus berkembang pesat menyebabkan manusia harus terus mengalami perubahan dalam berbagai aspek, baik dalam bidang ekonomi, sosial budaya, politik dan juga pola perilaku dalam melakukan dan menjalankan sebuah bisnis sehingga membuat persaingan yang semakin ketat . Setiap perusahaan tentunya ingin berhasil dalam menjalankan sebuah bisnisnya dan merek adalah sebuah aset yang paling berharga bagi sebuah perusahaan dimana merek sebagai alasan penting ketika konsumen ingin melakukan sebuah pengambilan keputusan dalam pembelian, dimana konsumen memiliki pengalaman terhadap kualitas sehingga menimbulkan kepercayaan mereka terhadap sebuah merek yang berfungsi sebagai alat ukur bagi konsumen bahwa merek mimiliki sebuah keunikan dan keunggulan yang dapat meningkatkan kepercayaan mereka. (Kremer dan Viot, 2012). Sedangkan merek menurut pasal 1 angka (1) undangundang no 20 tahun 2016, "merek adalah tanda yang dapat ditampilkan secara grafis berupa gambar, logo, nama, kata, huruf, angka, susunan warna, dalam bentuk 2 (dua) dimensi dan/atau 3 (tiga) dimensi, suara, hologram, atau kombinasi dari 2 (dua) atau lebih unsur 
tersebut untuk membedakan barang dan/atau jasa yang diproduksi oleh orang atau badan hukum dalam kegiatan perdagangan barang dan/atau jasa.

Dalam persaingan yang tajam seperti sekarang ini , sebuah perusahaan harus mampu bersaing dengan menciptakan ekuitas merek dimana ekuitas merek mempengaruhi konsumen dalam sebuah kepercayaan yang lebih besar dari pada merek pesaing dalam hal tertentu yang dapat mengingkatkan kemauan kosumen untuk membayar harga premium untuk sebuah merek dan meningkatkan loyalitas. (Lassar et al., 1995:11). Intinya, perusahaan yang memiliki ekuitas merek yang tinggi dapat dikatakan memiliki lebih banyak peluang untuk lebih sukses, memiliki lebih banyak keunggulan kompetitif, memiliki ketahanan terhadap tekanan promosi pesaing lain dan menciptakan hambatan bagi kompetitif sehingga sulit untuk masuk (Ling, 2013 dalam Suki dan Sasmita 2013).

Di Indonesia top brand sepatu olahraga adalah Adidas, dimana table brand index menunjukkan peringkat pertama adalah Adidas : 37,6\%, kedua Nike : 25,6\%, ketiga Reebok $: 6,2 \%$, keempat Ardiles :5,2\% , kelima Diadora :4,6\% (www.topbrand-award.com). Adidas pertama kali didirikan di Herzogenaurach, Jerman di tahun 1920 oleh Adolf Dassler dan Rudolph Dassler. Pada mulanya sebelum Adidas memproduksi sepatu hingga pakaian seperti sekarang ini. Adolf memproduksi selop. Hingga pada suatu hari Adolf merancang sepasang sepatu olahraga dan laku dipasaran karena kualitas dari sepatu Adidas yang sangat berkualitas tinggi. Pada tahun 1924 mereka mendirikan "Dassler Brothers OGH" yang menjadi Adidas sekarang ini.(sumber : www.sneakers.co.id). Sepatu Adidas memiliki brand equity dimana salah satu contohnya adalah logo Adidas yang bergambar tiga garis , walaupun tidak ada nama mereknya tapi orang-orang sudah tahu kalau itu adalah merek adidas.

Brand Awareness adalah situasi dimana konsumen mengasosiasikan merek dengan mendapatkan atau mencari informasi tentang merek dan merek yang mempunyai tingkat kesadaran yang lebih dapat dipertimbangkan untuk digunakan untuk memenuhi kebutuhannya. Brand Awareness sangat diperlukan pada proses komunikasi yang muncul pertama kali yaitu top of the mind awareness ( Macdonald and Sharp, 2003). Konsumen biasanya mendapatkan brand awareness melalui berbagai macam pemasaran yang ada contohnya saluran komunikasi yaitu smartphone, televisi, dan sebuah iklan online yang dapat membuat konsumen merasa memiliki jaminan terhadap kualitas produk dan dapat mengurangi risiko dalam mengevaluasi dan menyeleksi produk pada saat konsumen ingin membeli suatu produk. (Keller dan Lehmann, 2003, dalam Suki dan Sasmita 2013).

Menurut Romaniuk and Sharp, 2003 Brand Image adalah presepsi tentang merek yang berasal dari bermacam-macam sumber termasuk pengalaman yang diamalami oleh seorang konsumen, komunikasi pemasaran atau bisa melalui pemasaran dari mulut ke mulut Apabila sebuah merek memiliki kualitas yang tinggi maka konsumen akan merasa terhomat terhadap merek tersebut (Rubio et al., 2014). Brand image (alias toko gambar) adalah sebuah pandangan atau persepsi dari konsumen, dan lain-lain, dari merek, ketika sebuah merek sudah sering dilihat oleh konsumen maka konsumen cenderung dapat membantu sebuah perusahaan untuk lebih berkembang pesat dan merek tersebut biasa menjadi brand nomor satu dan mengambil penjualan yang besar saat ini (Burt dan Davies, 2010; Suki dan Samsita 2013). Bisa dilakukan dengan cara sebuah merek melakukan kerjasama dengan selebriti atau tokoh sejarah yang terkenal dalam menciptakan dimensi kepribadian dan ekstensi merek dalam iklan mereka. (Lau dan Phau, 2007). Seperti Adidas mengeluarkan sepatu yang diberi nama Arkyn, sneaker fashionable dari Adidas. Untuk kampanye global, merek Adidas mengajak Jenner, pemain sepakbola Florencia Galarza, desainer interior Marisa Competello, 
musisi Syv de Blare, serta artis Serbia Ana Kras sebagai fashion icon Adidas, dan di Indonesia bekerja sama dengan Jennifer Bachdim, penari Ufa Sofura, dan aktris Valerie Thomas, mereka dianggap memiliki banyak kreativitas dan tekun dalam berkarya. (kompas.com, 13/04/2018).

Dengan menciptakan brand loyalty pada konsumen, sebuah perusahaan harus melakukan komunikasi pemasaran yang berperan penting untuk menyakinkan konsumen pada kesetian merek tersebut (Šerić dan Gil-Saura, 2012). Yang akan membuat konsumen akan membeli lagi sebuah produk atau jasa yang disukainya berulang ulang kali, dan selalu memperioritaskan merek tersebut (Luarn dan Lin, 2003). Dengan kata lain, mereka menjadi setia dengan merek atau produk pilihan mereka dan tetap memilih merek yang terkenal (Sun et al., 2004), Dengan demikian, Penelitian ini bertujuan untuk meneliti brand awareness, brand image dan brand loyalty sebagai prediktor positif brand equity Adidas di Jakarta.

\section{KAJIAN TEORI}

Perkembangan ekonomi saat ini sangatlah ketat yang mengharuskan sebuah perusahaan untuk dapat memiliki keunggulan yang kompetitif. Salah satunya adalah merek, menurut undang-undang no 20 tahun 2016, "merek adalah tanda yang dapat ditampilkan secara grafis berupa gambar, logo, nama, kata, huruf, angka, susunan warna, dalam bentuk 2 (dua) dimensi dan/atau 3 (tiga) dimensi, suara, hologram, atau kombinasi dari 2 (dua) atau lebih unsur tersubut untuk membedakan barang dan/atau jasa yang diproduksi oleh orang atau badan hokum dalam kegiatan perdagangan barang dan/atau jasa.

Sehingga merek adalah asset yang tidak berwujud, tetapi banyak industri yang menganggap nilai yang terdapat pada suatu perusahaan merupakan nilai yang sangat penting. Nilai tersebut terbentuk dari sebuah kepercayaan yang diberikan oleh konsumen atau pelanggan terhadap merek perusahaan. Menurut Hidayat (2012) kepercayaan tersebut akan membentuk sebuah relasi antara pelanggan dan merek yang bersangkutan dan dapat menciptakan preferensi, loyalitas merk dan keinginan untuk mempertimbangkan barang atau jasa yang ditawarkan kepada konsumen.

Pada penelitian ini dibagi menjadi dua variabel yaitu yang pertama variabel independen yaitu brand awareness, brand loyalty dan brand image. Dan pada variabel ke dua yaitu variabel dependen yaitu brand equity. Variabel pada penelitian ini mempunyai sebuah keterikatan satu sama lain sehingga dapat menentukan brand equity pada suatu merek.

Ketika membangun sebuah brand equity, merek adalah hal yang paling penting harus dilakukan karena apabila brand equity sudah terbangun dengan baik maka akan memberikan hal yang positif juga kepada sebuah merek. Menurut Keller (2013) ketika seseorang memiliki brand equity yang kuat, maka pelanggan akan membeli lebih banyak dari Anda, dan mereka akan merekomendasikannya kepada kita dan kepada orang lain, mereka akan lebih setia dan Anda cenderung lebih sedikit kehilangan mereka.

Berdasarkan data diatas maka dapat dibuat sebuah kerangka pemikiran seperti gambar di bawah 


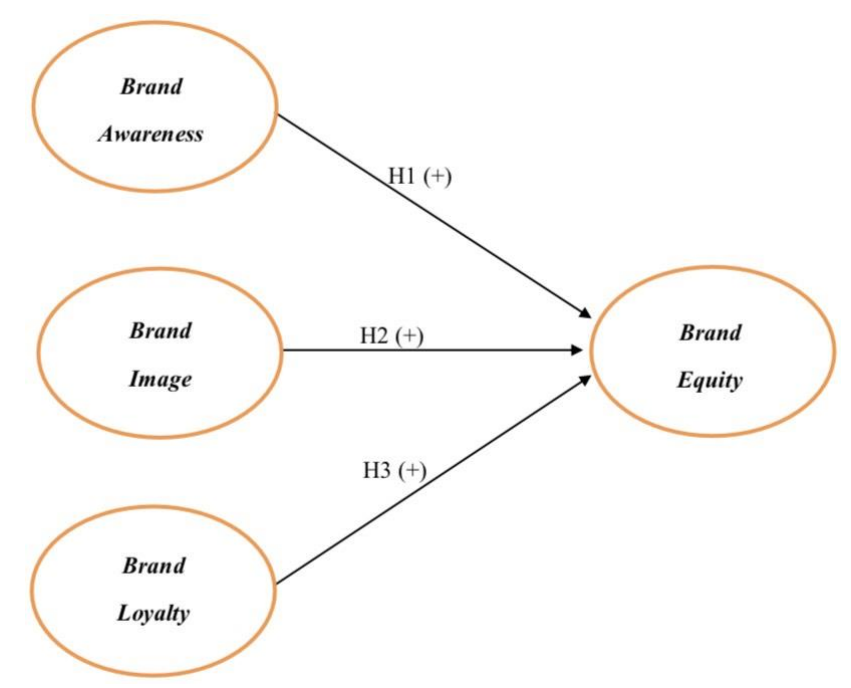

Dari kerangka pemikiran di atas, menghasilkan hipotesis (jawaban sementara), yaitu :

$\mathrm{H}_{1}$ : Brand awareness merupakan prediktor positif terhadap brand equity.

$\mathrm{H}_{2}$ : Brand image merupakan prediktor positif terhadap brand equity.

$\mathrm{H}_{3}$ : Brand loyalty merupakan prediktor positif positif terhadap brand equity.

\section{METODOLOGI}

Menurut Malhotra (2010, h. 100), menyatakan bahwa desain penelitian adalah " $a$ framework or blueprint for conducting the marketing research project. It specifies the details of procedures necessary for obtaining the information needed to structure and or solve marketing research problems." Dari penjelasan tersebut dijelaskan bahwa desain penelitian adalah sebuah kerangka kerja yang bertujuan untuk melakukan penelitian riset pemasaran agar dapat memeperoleh informasi dan masalah dalam riset pemasaran. Desain penelitian dibagi menjadi dua jenis yaitu penelitian konklusif dan penelitian eksploratif.

Menurut Malhotra (2010) terdapat dua jenis penelitian konklusif yaitu penelitian deskriptif dan penelitian kausal. Pada penelitian ini menggunakan penelitian deskriptif untuk mendapatkan sebuah gambaran tentang respons dari konsumen merek Adidas di Jakarta. Penelitian deskriptif dibagi menjadi dua yaitu cross-sectional dan longitudinal. Pada penelitian ini menggunakan cross-sectional dimana pengumpulan data sampel dilakukan sekali dalam satu waktu.

Menurut Malhotra (2010, h. 370), menyatakan bahwa populasi adalah "the aggregate of all the elements, sharing some common set of characteristics, that comprises the universe for the purpose of the marketing research problem." Dari penjelasan tersebut dapat dijelaskan bahwa populasi adalah semua elemen yang ada di alam semesta yang diperlukan dalam masalah riset pemasaran.

Populasi dalam penelitian ini adalah konsumen Adidas di Jakarta. Dimana merek Adidas terdapat di banyak belahan dunia, dan Adidas selalu bertahan di pasaran, maka dari penelitian ini tentang konsumen Adidas dan sampel di lakukan di Jakarta saja.

Menurut Malhotra (2010, h. 371), menyatakan bahwa sampel adalah " subgroup of the elements of the population selected for the participation in the study." Dari penjelasan tersebut dijelaskan bahwa populasi adalah sebuah kelompok populasi yang dipilih untuk partisipasi dalam sebuah penelitian. 
Pada penelitian ini menggunakan metode nonprobability sampling. Nonprobability sampling "sampling techniques that do not use chance selection procedures. Rather, they rely on the personal judgement of the researcher." Nonprobability sampling adalah sebuah teknik pengambilan sampel dimana peneliti secara sadar memutuskan pemilihan sampel dan bergantung pada penilaian peneliti secara pribadi Malhotra (2010: 376).

Teknik pemilihan sampel pada penelitian ini menggunakan convenience sampling. Convenience sampling adalah sebuah pengumpulan informasi dimana informasi tersebut didapatkan dari anggota populasi yang bersedia dan meyediakan informasi yang kita butuhkan (Sekaran \& Bougie, 2013). Ukuran sampel pada penelitian ini sebanyak 100 sampel dan hanya dari konsumen Adidas di Jakarta.

Dalam penelitian ini sampel yang di ambil sebanyak 100 responden dan hanya dari konsumen Adidas yang berlokasi Jakarta. Pengambilan sample yang efektif lebih dari 30 responden dan kurang dari 500 responden (Sekaran dan Bougie, 2013).

Tanggapan yang digunakan adalah format tipe skala Likert dengan memberikan tanggapan diantara 1-5, yaitu :

a. Nilai 5 tanggapan sangat setuju

b. Nilai 4 tanggapan setuju

c. Nilai 3 tanggapan netral

d. Nilai 2 tanggapan tidak setuju

e. Nilai 1 tanggapan sangat tidak setuju

\section{Hasil Uji Statistik}

Pengujian validitas data dalam penelitian ini diukur dengan menggunakan nilai loading factor, convergent validity, dan discriminant validity. Convergent validity dianggap memenuhi syarat apabila nilai average variance extracted (AVE) adalah $\geq 0,5$ dan setiap indikator diharuskan memiliki nilai loading factor $>0,7$. Hanseler, Ringle, dan Sinkovics (2009), Model penelitian dapat dihapuskan apabila suatu indikator yang memiliki nilai loading factor dibawah 0,4 .

Hasil Uji Validitas (AVE)

\begin{tabular}{|c|c|c|}
\hline Variabel & AVE & Evaluasi Model \\
\hline Brand Awareness & 0.712 & Valid \\
\hline Brand Image & 0.666 & Valid \\
\hline Brand loyalty & 0.727 & Valid \\
\hline Brand Equity & 0.796 & Valid \\
\hline
\end{tabular}

Hasil analisis Loading Factor

\begin{tabular}{|l|l|l|l|l|}
\hline Indikator & $\begin{array}{l}\text { Brand } \\
\text { Awareness }\end{array}$ & $\begin{array}{l}\text { Brand } \\
\text { Equity }\end{array}$ & $\begin{array}{l}\text { Brand } \\
\text { Image }\end{array}$ & $\begin{array}{l}\text { Brand } \\
\text { loyalty }\end{array}$ \\
\hline BA1 & 0,836 & & & \\
\hline BA2 & 0.888 & & & \\
\hline BA3 & 0.873 & & & \\
\hline BA4 & 0.766 & & & \\
\hline BA5 & 0,852 & & & \\
\hline BE2 & & 0,881 & & \\
\hline BE3 & & 0,868 & & \\
\hline BE4 & & 0,910 & & \\
\hline
\end{tabular}




\begin{tabular}{|l|l|l|l|l|}
\hline BE5 & & 0,909 & & \\
\hline BI1 & & & 0,822 & \\
\hline BI2 & & & 0,786 & \\
\hline BI3 & & & 0,840 & \\
\hline BI4 & & & 0,755 & \\
\hline BI5 & & & 0,873 & \\
\hline BL1 & & & & 0,857 \\
\hline BL2 & & & & 0,871 \\
\hline BL3 & & & & 0,831 \\
\hline BL4 & & & & 0,848 \\
\hline BL5 & & & 0,854 \\
\hline
\end{tabular}

Selanjutnya dilakukan analisis reliabilitas dengan menggunakan cornbach's alpha melalui perangkat lunak smart PLS. Pada reliabilitas indikator yang dianggap reliabel apabila nilai standardized loading $\geq 0,7$ (Hair et al. 2011) dan reliablitas konsistensi dianggap reiabel jika nilai composite reliability $\geq 0,70$ dan $<0,95$.

\begin{tabular}{|l|l|l|}
\multicolumn{2}{c}{ Hasil analisis reliabilitas } \\
\hline Variabel & Cronbach's Alpha & Composite Reliability \\
\hline Brand Awareness & 0,899 & 0,925 \\
\hline Brand Equity & 0,915 & 0,940 \\
\hline Brand Image & 0,875 & 0,909 \\
\hline Brand Loyalty & 0,906 & 0,930 \\
\hline
\end{tabular}

Nilai R-square juga digunakan untuk menghitung besarnya peranan atau pengaruh variabel bebas pada variabel tergantung. Apabila memiliki nilai koefisien antara 0 sampai 1 yang dikelompokkan menjadi 4 bagian yaitu nilai 0,25 adalah prediktif yang lemah, nilai 0,50 adalah prediktif yang moderat, nilai 0,75 adalah prediktif yang substantial, nilai 1 adalah koefisien yang merupakan prediktif yang akurat (Hair et al., 2011). besarnya koefisien determinasi yang disesuaikan $\left(\mathrm{R}^{2}\right)$ adalah sebesar 0,675 yang berarti bahwa sebesar 67,5\% dari variabel dependen Brand Equity dan penjelasan sisa sebesar 32,5\% (100\% $67,5 \%)$ dan juga dapat dikatakan koefisien determinasi $\left(\mathrm{R}_{2}\right)$ mempunyai pengaruh yang moderat.

Pengukuran pada path coefficients dilakukan untuk mengetahui bagaimana hubungan atau kaitan antar variabel-variabel yang terdapat dalam penelitian ini dengan yang lainnya. Hasil pengujian yang dilakukan menggunakan boothstrapping yaitu BA =0,203BA $+0,209 \mathrm{BI}+0,475 \mathrm{BL}$. Berdasarkan persamaan tersebut dapat diketahui bahwa brand loyalty memiliki kontribusi yang terbesar terhadap brand equity dengan path coefficients sebesar 0,475. Nilai path coefficients menunjukkan bahwa hubungan antara variabel brand awareness terhadap brand equity memiliki hasil yang positif sebesar 0,203, variabel brand image terhadap brand equity memiliki hasil yang positif sebesar 0,209 dan variabel brand loyalty terhadap brand equity memiliki hasil yang positif sebesar 0,475.

Pengujian pada effect size $\left(\mathrm{f}_{2}\right)$ dilakukan untuk mengetahui dampak pada perubahan atau efek yang terjadi pada sebuah model penelitian dengan keberadaan atau dihilangkan suatu variabel tertentu dari sebuah model model penelitian. Hasil pengujian effect size diuraikan pada table 4.12 di bawah ini. 
Tabel 4.12

Hasil pengujian Effect Size

\begin{tabular}{|c|c|}
\hline Variabel & Brand Equity \\
\hline Brand Awareness & 0,041 \\
\hline Brand Image & 0,027 \\
\hline Brand Loyalty & 0,232 \\
\hline
\end{tabular}

Berdasarkan hasil dari pengujian effect size yang diuraikan pada Tabel 4.12 diatas, dapat disumpulkan bahwa variabel brand awareness memiliki efek perubahaaan yang tergolong lemah terhadap brand equity yaitu sebesar 0,041, sedangkan variabel brand image memiliki efek perubahan yang tergolong lemah terhadap brand equity yaitu sebesar 0,027 dan variabel brand loyalty memiliki efek perubahan yang tergolong sedang terhadap brand equity yaitu sebesar 0,232

Kesimpulannya bahwa variabel brand loyalty merupakan satu variabel yang memberikan kontribusi yang paling besar terhadap brand equity dibandingkan dengan variabel brand awareness dan brand image.

Pada penelitian ini menggunakan PLS-SEM untuk menganalisis data pengujian tersebut disebut sebagai goodness-of-fit atau GoF. Menurut Tenenhaus et al. (2005) GoF merupakan sebuah solusi untuk permasalahan indeks validasi dalam PLS. berikut adalah perhitungan untuk goodness-of-fit Perhitungan nilai GoF diuraikan secara rinci di bawah ini.

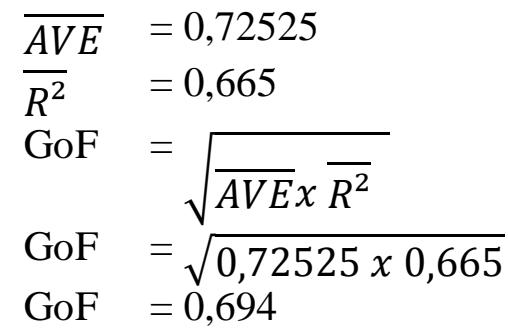

Menurut Hair et al. (2011) menjelaskan bahwa pengujian hipotesis untuk sebuah penelitian menggunakana metode PLS-SEM dapat dilihat dengan melihat nilai t-statistik yang terdapat pada variabel path coefficient dimana nilai t-statistik dapat diperoleh melalui metode boothstrapping.

Dalam penelitian ini, menggunakan taraf signifikansi 5\%, sehingga minimum yang digunakan dalam hipotesis ini sebesar 1,96. Ada dua kemungkinan dalam penelitian dalam melakukan hipotesis yaitu :

a. Hipotesis penelitian ditolak apabila nilai t-statistik pada model penelitian ini kurang dari nilai batas minimum dari 1,96 (t-value $=<1,96)$.

b. Hipotesis penelitian tidak ditolak apabila nilai t-statistik pada model penelitian ini melebihi batas minimum dari 1,96 $(\mathrm{t}-$ value $=>1,96)$.

Berikut adalah hasil pengujian hipotesis:

Hasil Uji hipotesis 1

\begin{tabular}{|c|c|c|}
\hline Hipotesis & Nilai & Keterangan \\
\hline $\begin{array}{c}\text { Brand Awareness } \\
\text { Brand Equity }\end{array}$ & Beta $=0,203$ & Positif \\
\cline { 2 - 3 } & P-Value $=0,011$ & Signifikan \\
\cline { 2 - 3 } & T Statistics $=2,296$ & Tidak Ditolak \\
\hline
\end{tabular}


Hasil Uji hipotesis 2

\begin{tabular}{|c|c|c|}
\hline Hipotesis & Nilai & Keterangan \\
\hline \multirow{2}{*}{$\begin{array}{c}\text { Brand Image -> } \\
\text { Brand Equity }\end{array}$} & Beta $=0,209$ & Positif \\
\cline { 2 - 3 } & $P$-Value $=0,024$ & Signifikan \\
\cline { 2 - 3 } & T Statistics $=1,982$ & Tidak Ditolak \\
\hline
\end{tabular}

Hasil Uji hipotesis 3

\begin{tabular}{|c|c|c|}
\hline Hipotesis & Nilai & Keterangan \\
\hline \multirow{2}{*}{$\begin{array}{c}\text { Brand Loyalty }-> \\
\text { Brand Equity }\end{array}$} & Beta $=0,475$ & Positif \\
\cline { 2 - 3 } & P-Value $=0,000$ & Signifikan \\
\cline { 2 - 3 } & T Statistics $=5,365$ & Tidak Ditolak \\
\hline
\end{tabular}

\section{DISKUSI}

Berdasarkan pengujian atas hipotesis yang telah terbentuk sebelumnya pada peneletian ini, kriteria untuk menentukan apakah hipotesis-hipotesis yang terdapat pada penelitian ini ditolak atau tidak ditolak adalah dengan melakukan pengujian boothstrapping lalu melihat hasil nilai $t$ statistics atau $p$ value sehingga memperoleh jawabaan bahwa

Pada Hipotesis pertama $\left(\mathrm{H}_{1}\right)$ menunjukkan bahwa brand awareness adalah sebuah prediktor positif terhadap brand equity merek Adidas. Terlihat dari brand awareness yang merupakan prediktor kuat terhadap brand equity sehingga semakin bagus untuk meningkatkan brand equity di mata para konsumen Adidas. Hasil tersebut sesuai dengan pernyataan Romaniuk, et al., 2017, yang menyatakan bahwa brand awareness adalah sebuah tahapan pertama untuk brand equity meskipun tidak langsung namun berpengaruh terhadap ekuitas merek secara keseluruhan dan brand awareness merupakan sebuah persyaratan untuk brand equity karena konsumen itu harus sadar bahwa ada merek tersebut. Menurut Shabbie et al 2017) bahwa brand awareness adalah sebuah pembangunan yang mengarah pada brand equity dan mempunyai sebuah efek tertentu pada persepsi-persepi dan sikap konsumen. Dan penelitian dari Sasmita dan Suki ( 2014) dimana brand awareness secara signifikan dapat mempengaruhi pengambilan keputusan konsumen dimana konsumen akan menggunakannya untuk keputusan heuristik yang dapat menguntungkan pnegelolaan brand equity. Sehingga semakin banyak konsumen yang sadar bahwa ada merek Adidas akan menciptakan peluang bagi merek Adidas sehingga semakin kuat dan merek Adidas akan terletak di pikiran konsumen.

Hasil pengujian kedua yaitu brand image merupakan prediktor yang positif terhadap brand equity merek Adidas. Brand image merupakan prediktor yang kuat terhadap brand equity sehingga terbukti bahwa $\mathrm{H}_{2}$ tidak ditolak . hasil menunjukkan sesuai dengan penelitian dahulu yang dikemukakan oleh Lee et al (2009) pada dasarnya brand image pada dasarnya brand image yang baik juga akan meningkatkan brand equity dan dapat membuat konsumen rela untuk membayar sehingga dapat memperoleh brand equity yang semakin besar. Dan apabila konsumen memiliki asumsi brand image Adidas akan dapat memperoleh keunggulan kompetitif bagi Adidas, penelitian ini sesuai dengan penelitian dari Fatema, Azad dan Masum (2013). Dan penelitian terdahulu Sasmita dan Suki ( 2014) menjelaskan bahwa brand image merupakan hubungan positif terhadap brand equity dimana memiliki hasil signifikan $(\beta=0.369$, t-value $=3.890, \mathrm{p}<0.005)$ ". Brand image yang harus diciptakan 
pada suatu merek haruslah yang baik bahkan harus mempunyai suatu konsep yang kuat seperti Adidas.

Selanjutnya adalah pengujian brand loyalty merupakan prediktor positif terhadap brand equity merek adidas. Dimana sesuai penelitian brand image merupkan prediktor positif terhadap brand equity sehingga terbukti bahwa $\mathrm{H}_{3}$ tidak ditolak dan diperkuat dengan peneliti sebelumnya yang menjelaskan bahwa dimana brand loyalty dapat mengambil suatu hal yang baik tentang suatu merek tersebut, sehingga dapat mempengaruhi pembeli untuk membeli merek tersebut (Fatema, Azad dan Masum 2013) dan Menurut penelitian dari Kim et al., (2008) brand loyalty merupakan pendorong utama pada brand equity. Dimana brand loyalty menjadi jalan dan dapat mengurangi biaya pemasaran, untuk memperoleh keuntungan, premi harga dan pedagang yang lain. Dan menurut Vogel et al., (2008) pada penjualan masa lalu untuk penjualan masa depan menciptakan hubungan antara brand loyalty terhadap brand equity yang memberikan dampak dari niat loyalitas.

\section{PENUTUP}

Berdasarkan hasil pengujian data dalam penelitian ini,maka dapat diambil kesimpulan yaitu : 1. Brand awareness merupakan prediktor terhadap brand equity Adidas di Jakarta. 2. Brand image merupakan prediktor terhadap brand equity Adidas di Jakarta. 3. Brand Loyalty merupakan prediktor terhadap brand equity Adidas di Jakarta.

Keterbatasan Sebuah penelitian tentu jauh dari kata sempurna termaksud pada penelitian ini. Keterbatasan dari penelitian ini adalah jangkauan pada penelitian ini hanya meneliti konsumen Adidas di Jakarta saja. Hanya meneliti dari 100 responden yang didapatkan selain itu waktu dari penelitian ini yang relatif singkat sehingga responden dari penelitian ini terbatas dan semakin kurang mempresentasikan pendapat dari masyarakat di Jakarta.

Saran Terkait dengan hasil penelitian ini, peneliti mau memberikan beberapa saran yang terkait dengan Adidas sekiranya saran ini dapat bermanfaat bagi perusahaan Adidas. Brand awareness merupakan prediktor positif terhadap brand equity Adidas di Jakarta.

Saran yang diberikan peneliti sebagai berikut : a) Peneliti menyarankan Adidas untuk terus meningkatkan dan mempertahankan brand awareness untuk masyarakat Jakarta dengan terus mengikuti acara-acara yang ada seperti pekan olahraga yang diselenggaran di Jakarta maupun luar Jakarta, dengan menjadi sponsor sehingga nama atau merek Adidas selalu muncul yang menciptakan masyarakat selalu sadar dengan adanya merek Adidas, dan dengan melakukan iklan melalui televisi, radio, Koran terutama di media sosial seperti iklan di Facebook, Instagram, Line dan lain sebagainnya, Bekerja sama dengan artis atau model yang terkenal sehingga mereka dapat mempromosikan merek Adidas sehingga lebih banyak masyarakat yang sadar dan tetap setia kepada merek Adidas. Membuka lebih banyak gerai Adidas di Indonesia. b) Peneliti menyarankan Adidas untuk membuat brand image Adidas yang selalu relevan bagi semua kalangan usia dan mengikuti model-model yang baru dengan trend masa kini selalu menciptakan produk-produk yang enak digunakan akan tetapi harus tetap pada konsep utama Adidas yang mengutamakan casual sportswear. Dan harus selalu menciptakan layanan yang baik dan bagus dengan berbagai konsep yang baik di offline store maupun online store karena image yang baik dan bagus akan menciptakan image yang baik dan bagus juga, dan akan membuat merek Adidas akan selalu ada dipikiran para konsumen dan tidak akan berpaling ke merek lain, karena image yang buruk pada sebuah merek akan sangat mempengaruhi konsumen. c) Peneliti menyarankan Adidas dalam brand loyalty untuk 
membuat konsumen selalu setia kepada merek adidas dengan selalu memberikan layanan yang terbaik, memberikan promo - promo kepada konsumen baru agar menjadi setia dan loyal maupun kepada konsumen lama agar semakin setia dan loyal kepada merek Adidas dan memberikan hadiah kepada pelanggan setia Adidas tidak perlu memberi hadiah yang terlalu mahal bisa seperti handuk kecil, kaos kaki, kupon dan lain sebaginya walaupun itu tidak terlalu mahal namun sangat berkesan bagi konsumen. Selalu menginformasikan halhal baru seperti produk baru dan promo terbaru Adidas kepada para konsumen sehingga konsumen terpancing untuk membeli dan tetap setia kepada Adidas. Mendata konsumen setia Adidas sehingga saat konsumen ulang tahun Adidas bisa menggucapkan selamat ulang tahun dan memberikan hadiah ataupun diskon sehingga konsumen Adidas merasa mereka dihargai dan tetap setia kepada merek Adidas. d) Untuk peneliti lain, disarankan untuk menggunakan variabel-variabel lain selain dari variabel pada penelitian ini sehingga dapat mengetahui varaibel lain yang dapat memprediksi brand equity. Dan disaranakan untuk melakukan penelitian selanjutnya dengan menambah jumlah responden karena lebih banyak responden akan memberikan jawaban yang lebih beragam lagi dan memperluas jangkauan penelitian.

\section{DAFTAR PUSTAKA}

Fatema, M., Azad, Md.A.K., Masum, A.K.M. (2013). Impact of Brand Image and Brand Loyalty in Measuring Brand Equity of Islami Bank Bangladesh Ltd.

Hair, J., Ringle, C., \& Sarstedt, M. (2011). PLS-SEM: Indeed A Silver Bullet. "The Journal of Marketing Theory and Practice, 19(2), 139-151.

Hanseler,J., Ringle, C. M., \& Sinkovics, R. R.(2009). The Use of Partial Least Squares Path Modeling. International Marketing. 298-299.

Hidayat, A.P. (2012). Manajemen Pemasaran (Topik: Brand Equity/ Ekuitas Merek).

Keller, K. L. (2013). Strategic Brand Management: Building, Measuring, and Managing Brand Equity. England: Pearson Education Limited.

Kim Ka , Kim Kb , Kim D, Kim J, Kang S (2008). Brand Equity in Hospital Marketing. J. Bus. Res., 61: 75-82. DOI:10.1016/j.jbusres.2006.05.010.

Kremer, F. and Viot, C. (2012). How store brands build retailer brand image, International Journal of Retail \& Distribution Management, Vol. 40 No. 7, pp. 528-543.

Lassar, W., Mittal, B. and Arun, S. (1995). Measuring consumer based brand equity, Journal of Consumer Marketing, Vol. 12 No. 4, pp. 11-19.

Lau, K. C., \& Phau, I. (2007). Extending symbolic brands using their personality: Examining antecedents and implications towards brand image fit and brand dilution. Psychology and Marketing, 24(5), 421-444.

Lee, H.M., Lee, C.C., \& Wu, C.C. (2009). Brand image strategy affects brand equity after M\&A”. Europian journal of marketing, 45(7/8), 1091-1111.

Luarn, P. and Lin, H.H. (2003). A customer loyalty model for e-service context, Journal of Electronic Commerce Research, Vol. 4 No. 4, pp. 157-167.

Macdonald, E. and Sharp, B. (2003). Management perceptions of the importance of brand awareness as an indication of advertising effectiveness, Marketing Bulletin, Vol. 14 No. 2, pp. 1-11.

Maholtra, N. K. (2010). Essentials of Marketing Research. England: Pearson Educated Limited. 
Romaniuk, J., \& Sharp, B. (2003). Measuring brand perceptions: Testing quantity and quality. Journal of Targeting, Measurement and Analysis for Marketing, 11(3), 218229.

Rubio, N., Oubiña, J. and Villaseñor, N. (2014). Brand awareness-brand quality inference and consumer's riskperception in store brands of food products, Food Quality and Preference, Vol. 32 No. 2014, pp. 289-298.

Sasmita,J., \& Suki, N.M. (2015). Young consumers' insights on brand equity: Effects of brand association, brand loyalty, brand awareness, and brand image, International Journal of Retail \& Distribution Management, Vol. 43 Issue: 3, pp.276-292

Sekaran, U., \& Bougie, R. (2013). Research Methods for Business $6^{\text {th }}$ ed. Italy: Printer Trento Srl.

Šerić, M., \& Gil-Saura, I. (2012). ICT, IMC, and Brand Equity in High-Quality Hotels of Dalmatia: An Analysis From Guest Perceptions. Journal of Hospitality Marketing \& Management, 21(8), 821-851.

Shabbir, M.Q., Khan, A.A., \& Khan,A.R. (2017). "Brand loyalty brand image dan brand equity: the mediating role of brand awareness". Internasional Journal of Innovation and Applied Studies, 19(2), 416-423.

Sun, T., Horn, M. and Merritt, D. (2004), Values and lifestyles of individualists and collectivists: a study on Chinese, Japanese, British and US consumers, Journal of Consumer Marketing, Vol. 21 No. 5, pp. 318-331.

Tenenhaus, M., Vinzi, V. E., Chatelin, Y. M., \& Lauro, C. (2005). PLS Path Modeling. Computational Statistics \& Data Analysis, 48(1), 159-205.

Undang-Undang no 20 tahun 2016 "merek"

Vogel, V., Evanschitzky, H., Ramaseshan.,B. (2008), Customer Equity Drivers and Future Sales. Journal of Marketing Vol. 72, 98-108.

https://www.topbrand-award.com/en/2018/07/sepatu-olahraga-2018/

https://www.sneakers.co.id/sejarah-sepatu-adidas/

https://lifestyle.kompas.com/read/2018/04/13/112435720/arkyn-sneaker-fashionable-dari$\underline{\text { adidas }}$ 